\title{
FORMULASI DAN KARAKTERISASI MI BEBAS GLUTEN TINGGI PROTEIN BERBAHAN PATI SAGU YANG DISUBSTITUSI TEPUNG KACANG-KACANGAN
}

\section{(Formulation and characterization of free gluten high protein sago starch noodle subtituted with beans flour)}

\author{
Friska Citra Agustia ${ }^{1 *}$,Yovita Puri Subardjo ${ }^{1}$, Almira Sitasari ${ }^{2}$ \\ ${ }^{1}$ Prodi Ilmu Gizi, Fakultas Ilmu-ilmu Kesehatan, Universitas Jenderal Soedirman, Purwokerto 53123 \\ ${ }^{2}$ Jurusan Gizi, Politeknik Kesehatan Yogyakarta, Kementerian Kesehatan Republik Indonesia 55293
}

\begin{abstract}
The aims of the research were to determine the best formula and characteristics of free gluten with high protein sago starch noodles substituted with beans flour. A factorial random design was used for the experiment. Ratio of sago starch to red and green bean substitution were 100:0; 90:10; 80:20; 70:30. Variables analyzed were 1) chemical properties (water content, total fat, total protein, carbohydrate by difference and ash content) and 2) sensory properties. Hedonic test was conducted to determine the level of consumer acceptance of 15 semi-trained panelists. Data were analyzed by F-test and Duncan's Multiple Range Test (DMRT). The best formula was sago starch noodle from sago starch $70 \%$ and red bean $30 \%$ with protein content $10.47 \%$ dry weight $(d w)$; fat content $1.17 \%$ dw; water content $68.99 \%$ wet weight (ww); ash was $1.19 \% d w$ and carbohydrate by different was $18.18 \% d w$. The hedonic test values were 2.44 (like slightly); color 2.77 (yellow-brown), texture 2.59 (chewy slightly) and flavour 2.50 (rather good).
\end{abstract}

Keywords: green bean, red bean, sago starch noodle

\begin{abstract}
ABSTRAK
Tujuan dari penelitian ini adalah menetapkan formula mi pati sagu yang diperkaya tepung kacangkacangan dengan tingkat penerimaan dan kadar protein yang tinggi dan menetapkan karakteristik mi pati sagu yang diperkaya tepung kacang-kacangan dengan formula terbaik. Rancangan penelitian menggunakan Rancangan Acak Faktorial. Faktor perlakuan terdiri atas : jenis tepung substitusi (T) yaitu tepung kacang hijau dan kacang merah dan proporsi berat pati sagu-tepung substitusi (P) 100:0; 90:10; 80:20;70:30. Variabel yang dikaji adalah sifat kimia (kadar air, lemak total, protein total, karbohidrat by difference dan kadar abu); dan sifat sensori. Uji sensori dilakukan dengan metode rating hedonik dengan 15 panelis semi terlatih. Produk dibuat tiga kali ulangan. Data dianalisis dengan Uji F dan dilanjutkan dengan Duncan's Multiple Range Test (DMRT). Kombinasi terbaik dari perlakuan proporsi pati sagu: tepung kacang merah (70\%:30\%) (T2P3) memiliki kadar protein total 10,47\% bk ; kadar lemak 1,17\% bk ; kadar air 68,99 \% bb ; kadar abu 1,19\% bk dan kadar karbohidrat by difference $18,18 \% \mathrm{bk}$; warna 2,77 (kuning-cokelat), tekstur 2,59 (agak kenyal), flavor 2,50 (agak enak) dan kesukaan 2,44 (agak suka).
\end{abstract}

Kata kunci: kacang hijau, kacang merah, mi pati sagu

\section{PENDAHULUAN}

Mi adalah makanan pokok yang digemari oleh segala usia dan biasa disajikan bervariasi dalam menu sehari-hari. Mi juga merupakan salah satu dari makanan paling digemari anak sebagai menu sarapan (Perdana \& Hardinsyah
2013). Pembuatan mi biasanya menggunakan bahan dasar tepung terigu, namun dalam usaha diversifikasi pangan dikembangkan mi yang terbuat dari bahan pati sagu. Menurut $\mathrm{Hu}$ et al. (2007), mi dari pati sagu berbeda dengan mi dari terigu yang mengandalkan gluten untuk membentuk jaringan viskoelastis yang memberikan tekstur ke-

$\overline{\text { "Korespondensi: Telp: }}+62281621122$, Surel: furissuka@yahoo.co.id 
nyal. Proses ekstrusi pada pengembangan produk mi pati dan pasta dari bahan non terigu sangat diperlukan. Hal ini dikarenakan menurut Tam et al. (2004), pengolahan mi pati sangat mengandalkan proses gelatinisasi yang biasanya dapat terjadi saat proses ekstrusi. Pada pembuatan mi pati, proses ekstrusi terjadi pada tahapan pencetakan mi dalam alat.

Mi pati dari sagu $100 \%$ memiliki kadar protein rendah yaitu 5,82 \%bb (Auliah 2012). Syarat minimal kadar protein pada mi berdasarkan SNI 01-2987-1992 adalah 8\%. Salah satu alternatif untuk meningkatkan kadar protein dari mi tersebut adalah dengan menambahkan tepung kacang-kacangan yang merupakan sumber protein. Kacang hijau dan kacang merah merupakan jenis kacang-kacangan yang mengandung protein cukup tinggi sehingga sangat cocok digunakan sebagai substitusi dalam pembuatan mi pati sagu untuk meningkatkan kadar proteinnya. Sebuah penelitian menyebutkan bahwa kacang hijau kaya akan protein $(14,6-33,0 \mathrm{~g} / 100 \mathrm{~g})$ dan zat besi (5,9-7,6 mg/100 g) (Dahiya et al. 2015). Kacang hijau mengandung protein $22 \%$ serta vitamin $\mathrm{B} 1$, vitamin $\mathrm{A}$, dan vitamin $\mathrm{C}$ tinggi. $\mathrm{Be}-$ berapa penelitian menyebutkan bahwa tepung kacang-kacangan seperti tepung kacang hijau dapat dimasukkan dalam pembuatan mi (Chillo et al. 2010). Menurut Audu dan Aremu (2011), tepung kacang merah (Phaseolus vulgaris L) kaya protein nabati, karbohidrat kompleks, serat, vitamin $\mathrm{B}$, folasin, tiamin, kalsium, dan zat besi. Dalam $100 \mathrm{~g}$ kacang merah mengandung protein $15,3 \mathrm{~g}$; lemak 15,8 g; karbohidrat $49 \mathrm{~g}$; serat 3,6 $\mathrm{g}$; abu 4,4 g; kalsium $54 \mathrm{mg}$; fosfor 3,7 mg; besi $11,5 \mathrm{mg}$; kalium 14,5 mg.

Mi pati sagu yang dibuat pada penelitian ini berbentuk mi basah. Menurut SNI 01-29871992, mi basah adalah produk makanan yang terbuat dari tepung terigu dengan atau tanpa penambahan bahan lain dan bahan makanan yang diijinkan, berbentuk khas mi yang tidak dikeringkan. Bahan yang ditambahkan adalah tepung kacang hijau maupun tepung kacang merah sebagai sumber protein. Mi berbahan dasar pati memiliki tekstur kekerasan yang tinggi (Hormdok \& Noomhorn 2007). Pemberian kacang hijau diharapkan dapat memperbaiki karakteristik mi yaitu menurunkan kekerasan. Pati kacang hijau merupakan bahan pembuat starch noodle terbaik karena kandungan amilosanya yang tinggi (Muhammad et al. 1999). Sodium tripolyphosphat (STPP) 0,3\% juga ditambahkan untuk memperbaiki tekstur (kekenyalan mi pati sagu). Gardjito et al. (2013) menyatakan bahwa penambahan STPP sebesar 0,3\% mampu memperbaiki penam- pakan mi pati sagu yang diberi penambahan bahan lain sebagai substitusi. Tujuan penelitian ini untuk mengetahui jenis tepung substitusi dan proporsi pati sagu-tepung substitusi (tepung kacang hijau dan kacang merah) untuk mendapatkan mi dengan kandungan protein tinggi dan sifat organoleptik yang dapat diterima.

\section{METODE}

\section{Desain, tempat dan waktu}

Penelitian ini menggunakan desain eksperimental. Rancangan yang digunakan adalah rancangan acak lengkap (RAL). Faktor perlakuan terdiri atas; Jenis Tepung Substitusi (T) dan Proporsi Pati Sagu: Tepung Substitusi $(\mathrm{P} ; \mathrm{b} / \mathrm{b})$.

Penelitian dilakukan di Laboratorium Gizi Kuliner Prodi Ilmu Gizi UNSOED dan Laboratorium Teknologi Pertanian Jurusan Teknologi Pertanian UNSOED. Penelitian dilaksanakan pada Bulan Mei hingga September 2014.

\section{Bahan dan alat}

Pati sagu sebagai bahan utama yang digunakan pada penelitian ini adalah merek Alini, sedangkan kacang merah dan kacang hijau diperoleh dari Pasar Wage Purwokerto, STPP dan garam diperoleh dari Toko Inti Sari Purwokerto. Alat yang digunakan antara lain alat untuk pembuatan tepung, alat untuk pembuatan mi dan alat untuk analisis kimia.

\section{Tahapan penelitian}

Penelitian ini dilakukan dalam beberapa tahapan yaitu persiapan alat dan bahan; pembuatan tepung substitusi; uji kadar air, lemak dan protein tepung substitusi; dan pembuatan mi dengan beberapa kombinasi perlakuan. Mi yang dijadikan sebagai kontrol yaitu mi dengan bahan dasar $100 \%$ pati sagu.

Pembuatan tepung kacang hijau dan kacang merah. Kacang hijau dan kacang merah disortasi lalu dilakukan perendaman dalam air selama delapan jam, setelah itu dicuci dengan air mengalir dan dilakukan hot water blanching selama 15 menit. Tahapan selanjutnya dilakukan pengeringan dengan menggunakan cabinet dryer pada suhu $55-60^{\circ} \mathrm{C}$ selama $\pm 24 \mathrm{jam}$. Adonan kemudian digiling hingga halus kemudian diayak dengan ayakan 60 mesh sehingga didapatkan tepung kacang hijau dan kacang merah.

Pembuatan mi pati sagu substitusi tepung kacang hijau dan kacang merah. Sebanyak $20 \%$ tepung komposit (campuran pati sagu dan tepung kacang hijau atau kacang merah) dicampur homogen dengan bahan lain yaitu air 60\%, STPP 
0,3\% dan garam 1,5\% lalu dimasak hingga kental dan didapatkan adonan pasta pati sagu. Adonan pasta pati sagu ini kemudian dicampur dengan $80 \%$ tepung komposit dan dilakukan pengadonan hingga kalis. Setelah itu dilakukan pencetakan dengan cetakan mi dan direbus dalam air mendidih selama satu menit sampai mengapung kemudian ditiriskan.

Perbandingan bahan dan substitusi dalam pembuatan mi diambil dari penelitian Chairil dan Kustiyah (2014). Tabel 1 menunjukkan perbandingan antara tepung kacang yang digunakan sebagai substitusi dalam pembuatan mi.

Tabel 1. Perbandingan penggunaan tepung kacang dalam pembuatan mi

\begin{tabular}{lcccc}
\hline & P0 & P1 & P2 & P3 \\
& $100: 0$ & $90: 10$ & $80: 20$ & $70: 30$ \\
\hline $\begin{array}{l}\text { Tepung kacang } \\
\text { hijau (T1) }\end{array}$ & T1 P0 & T1 P1 & T1 P2 & T1 P3 \\
$\begin{array}{l}\text { Tepung kacang } \\
\text { merah (T2) }\end{array}$ & T2 P0 & T2 P1 & T2 P2 & T2 P3 \\
\hline
\end{tabular}

Uji sensori produk. Uji sensori (Soekaro 1985) dilakukan untuk mengetahui tingkat penerimaan konsumen terhadap warna, tekstur, flavor dan kesukaan mi pati sagu. Pengujian ini dilakukan oleh panelis semi terlatih sebanyak 15 orang (yang sebelumnya dilatih untuk mengetahui parameter-parameter tertentu yang akan diujikan) tanpa pengolahan lanjutan (tanpa dimasak dan tanpa dicampur dengan bumbu) dengan metode uji skoring. Uji ini memberikan nilai secara kuantitatif dengan skoring (angka) yang sudah disepakati sebelumnya yaitu antara range 1 (terendah) sampai range 4 (tertinggi). Pengujian terhadap kesukaan (hedonik) dilakukan terhadap mi yang telah diolah menjadi mi goreng dan telah dibumbui (dengan persentase bumbu yang sama) yang disajikan kepada panelis. Hal ini dikarenakan pengujian kesukaan produk disesuaikan dengan kebiasaan cara mengkonsumsi produk mi tersebut.

\section{Pengolahan dan analisis data}

Mi pati sagu juga dianalisis mutu gizinya meliputi kadar air (metode oven), kadar abu (metode gravimetri), protein (metode mikrokjedahl), lemak (metode soxhlet) dan karbohidrat by difference (Sudarmadji et al. 1984). Data dianalisis menggunakan analisis of variance atau analisis ragam atau uji Fischer (uji F) pada taraf 95\% dan apabila ada pengaruh nyata dilanjutkan dengan Duncan's Multiple Range Test (DMRT) pada taraf $5 \%$.

\section{HASIL DAN PEMBAHASAN}

\section{Tepung kacang hijau dan tepung ka- cang merah}

Tabel 2 menunjukkan kadar air, kadar lemak dan kadar protein total tepung kacang hijau dan tepung kacang merah. Kadar protein tepung kacang hijau dan tepung kacang merah cukup tinggi yaitu berturut-turut $23,66 \%$ bk dan 21,11 \%bk. Menurut Auliah (2012) mi yang terbuat dari $100 \%$ sagu memiliki kadar protein 5,82 \%bb dan syarat standar mutu nasional mi basah untuk kadar protein minimal adalah 8\% (SNI 01-29871992). Oleh karena itu, tepung kacang hijau dan tepung kacang merah sesuai digunakan sebagai tepung substitusi pada pembuatan mi pati sagu untuk meningkatkan kadar proteinnya.

Tabel 2. Kadar air, kadar lemak dan kadar protein total pati sagu, tepung kacang hijau dan tepung kacang merah

\begin{tabular}{lccc}
\hline \multicolumn{1}{c}{ Bahan } & $\begin{array}{c}\text { Kadar Air } \\
(\% \mathrm{bb})\end{array}$ & $\begin{array}{c}\text { Lemak } \\
(\% \mathrm{bk})\end{array}$ & $\begin{array}{c}\text { Protein } \\
(\% \mathrm{bk})\end{array}$ \\
\hline $\begin{array}{l}\text { Pati sagu } \\
\text { (merek alini) }\end{array}$ & 8,11 & 0,21 & 0,72 \\
$\begin{array}{l}\text { Tepung kacang } \\
\text { hijau }\end{array}$ & 7,21 & 1,53 & 23,66 \\
$\begin{array}{l}\text { Tepung kacang } \\
\text { merah }\end{array}$ & 8,35 & 1,78 & 21,11 \\
\hline
\end{tabular}

\section{Sifat kimia mi pati sagu substitusi tepung ka- cang}

Hasil Analisis Ragam (Uji F) dan DMRT $5 \%$ sifat kimia mi pati sagu dapat dilihat pada Tabel 3. Hasil uji statistik menunjukkan bahwa secara umum perlakuan jenis tepung substitusi (T) hanya berpengaruh terhadap kadar air mi pati sagu, sedangkan perlakuan proporsi pati sagu tepung substitusi $(\mathrm{P})$ berpengaruh terhadap kadar protein dan lemak mi pati sagu tetapi tidak berpengaruh terhadap variabel lainnya. Kombinasi perlakuan jenis tepung substitusi dan proporsi pati sagu-tepung subsitusi (TxP) tidak berpengaruh terhadap semua variabel kimia.

\section{Kadar air}

Kadar air mi pati sagu tanpa penambahan tepung substitusi (kontrol) adalah $65,01 \% \mathrm{bb}$, sedangkan menurut Tabel 3, kadar air mi pati sagu dengan penambahan tepung substitusi berkisar antara $66-73 \%$. Hal ini sesuai dengan penelitian Auliah (2012), mi yang terbuat dari tepung jagung:tepung sagu (1:30) memiliki kadar air $72,58 \%$. 
Agustia dkk.

Tabel 3. Hasil analisis ragam (uji F) dan DMRT 5\% sifat kimia mi pati sagu

\begin{tabular}{|c|c|c|c|c|c|}
\hline & $\begin{array}{c}\text { Air } \\
(\% \mathrm{bb})\end{array}$ & $\begin{array}{c}\text { Abu } \\
(\% \mathrm{bk})\end{array}$ & $\begin{array}{l}\text { Protein } \\
(\% \mathrm{bk})\end{array}$ & $\begin{array}{l}\text { Lemak } \\
(\% \mathrm{bk})\end{array}$ & $\begin{array}{l}\text { Karbohidrat } \\
(\% \mathrm{bk})\end{array}$ \\
\hline \multicolumn{6}{|c|}{$\begin{array}{c}\text { Pengaruh Jenis } \\
\text { Tepung Substitusi (T) }\end{array}$} \\
\hline $\mathrm{T} 1$ & $65,896 \mathrm{~b}$ & 1,063 & 5,643 & 0,770 & 26,628 \\
\hline $\mathrm{T} 2$ & $69,673 \mathrm{a}$ & 1,120 & 5,860 & 0,790 & 26,912 \\
\hline \multicolumn{6}{|c|}{ Pengaruh Proporsi (P) } \\
\hline P0 & 65,957 & 1,037 & $0,822 \mathrm{~d}$ & $0,353 \mathrm{~d}$ & 31,690 \\
\hline $\mathrm{P} 1$ & 69,385 & 1,010 & $4,170 \mathrm{c}$ & $0,697 \mathrm{c}$ & 27,425 \\
\hline $\mathrm{P} 2$ & 67,767 & 1,138 & $7,568 \mathrm{~b}$ & $0,920 \mathrm{~b}$ & 22,633 \\
\hline P3 & 68,030 & 1,180 & $10,447 \mathrm{a}$ & $1,150 \mathrm{a}$ & 25,332 \\
\hline \multicolumn{6}{|c|}{ Pengaruh Interaksi (TxP) } \\
\hline $\mathrm{T} 1 \mathrm{P} 0$ & $65,02 \pm 0,86$ & $1,03 \pm 0,19$ & $0,74 \pm 0,08$ & $0,38 \pm 0,15$ & $32,84 \pm 0,13$ \\
\hline $\mathrm{T} 1 \mathrm{P} 1$ & $65,04 \pm 1,04$ & $0,93 \pm 0,12$ & $4,06 \pm 0,23$ & $0,65 \pm 0,11$ & $29,32 \pm 0,13$ \\
\hline $\mathrm{T} 1 \mathrm{P} 2$ & $66,45 \pm 1,32$ & $1,13 \pm 0,25$ & $7,35 \pm 0,46$ & $0,92 \pm 0,04$ & $24,16 \pm 0,35$ \\
\hline T1P3 & $67,07 \pm 0,38$ & $1,17 \pm 0,09$ & $10,43 \pm 0,47$ & $1,13 \pm 0,08$ & $20,19 \pm 0,01$ \\
\hline $\mathrm{T} 2 \mathrm{P} 0$ & $65,02 \pm 1,7$ & $1,05 \pm 0,08$ & $0,70 \pm 0,14$ & $0,37 \pm 0,12$ & $32,54 \pm 0,39$ \\
\hline $\mathrm{T} 2 \mathrm{P} 1$ & $73,72 \pm 0,48$ & $1,09 \pm 0,17$ & $4,28 \pm 0,36$ & $0,74 \pm 0,12$ & $25,53 \pm 0,07$ \\
\hline $\mathrm{T} 2 \mathrm{P} 2$ & $69,08 \pm 0,59$ & $1,15 \pm 0,13$ & $7,79 \pm 0,64$ & $0,92 \pm 0,09$ & $21,11 \pm 0,05$ \\
\hline $\mathrm{T} 2 \mathrm{P} 3$ & $68,99 \pm 0,83$ & $1,19 \pm 0,06$ & $10,47 \pm 0,59$ & $1,17 \pm 0,08$ & $18,18 \pm 0,56$ \\
\hline
\end{tabular}

*Angka yang diikuti huruf (a,b,c,d) yang berbeda pada kolom yang sama menunjukkan berbeda nyata pada DMRT 5\%;T1P0 (tepung kacang hijau, P0=100:0); T1P1(tepung kacang hijau, P1=90:10); T1P3(tepung kacang hijau, $\mathrm{P} 3=70: 30$ ), T2P0 (tepung kacang merah, $\mathrm{P} 0=100: 0$ ); T2P1 (tepung kacang merah, $\mathrm{P} 1=90: 10$ ); T2P2 (tepung kacang merah, $\mathrm{P} 2=80: 20$ ); $\mathrm{T} 2 \mathrm{P} 3$ (tepung kacang merah, $\mathrm{P} 0=70: 30$ ).

Penambahan tepung substitusi kaya protein meningkatkan kadar air mi pati sagu karena adanya gugus polar pada protein yang dapat mengikat air. Nilai rata-rata kadar air mi pati sagu yang di substitusi tepung kacang hijau $(65,89 \%)$ lebih kecil dibandingkan nilai rata-rata kadar air mi pati sagu yang disubstitusi tepung kacang merah $(9,67 \%)$. Hal ini dikarenakan kadar air kacang merah yang digunakan lebih tinggi dibandingkan dengan kacang hijau yaitu berturut-turut $8,35 \%$ dan $7,21 \%$ sehingga akan mempengaruhi kadar air mi pati sagu.

\section{Kadar abu}

Hasil penelitian menunjukkan rata-rata kadar abu mi pati sagu yang disubstitusi tepung kacang hijau dan tepung kacang merah adalah $0,93-1,19 \%$ bk. Hal ini sesuai dengan penelitian Omeire et al. (2015), mi yang disubstitusi kacang bambara yaitu dibuat dari terigu-ubi kayukacang bambara (80:10:10)\%b/b memiliki kadar abu berkisar $1,8 \%$ bk.

\section{Kadar protein dan kadar lemak}

Gambar 1 dan 2 masing-masing menunjukkan nilai rata-rata kadar protein total dan kadar

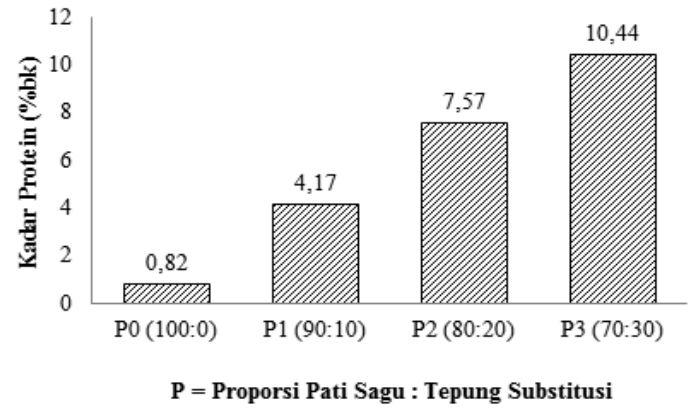

Keterangan : Angka yang diikuti huruf yang sama tidak berbeda nyata pada DMRT 5\%

Gambar 1. Nilai rata-rata kadar protein total mi pati sagu pada perlakuan proporsi pati sagu-tepung substitusi.

lemak total mi pati sagu pada perlakuan proporsi pati sagu-tepung substitusi. Semakin tinggi proporsi tepung substitusi yang ditambahkan, maka semakin tinggi pula kadar protein total dan kadar lemaknya. Nilai rata-rata kadar protein tertinggi diperoleh dari proporsi pati sagu-tepung substitusi terbesar (70:30) yaitu $10,44 \% \mathrm{bk}$, sedangkan nilai terendah diperoleh dari mi pati sagu tanpa penambahan tepung substitusi yaitu $0,82 \%$ bk. 


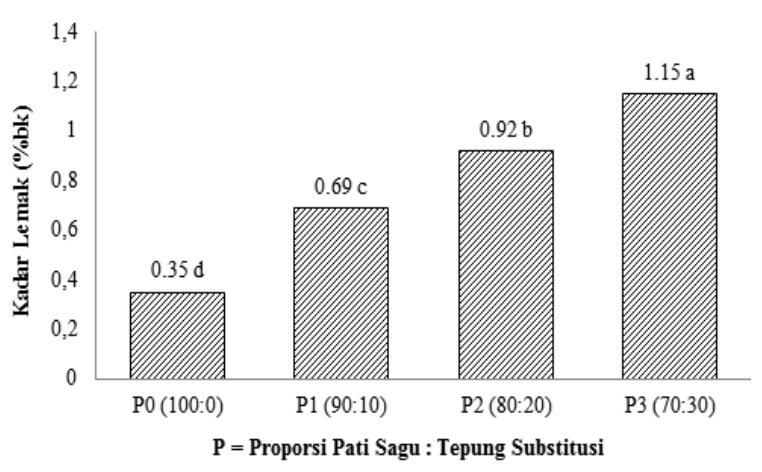

Keterangan : Angka yang diikuti huruf yang sama tidak berbeda nyata pada DMRT 5\%

Gambar 2. Nilai rata-rata kadar lemak total mipati sagu pada perlakuan proporsi pati sagu-tepung substitusi.

Kadar protein dan lemak kacang hijau berturut-turut 23,8\% dan 1,22\% (Dahiya et al. 2014), serta kadar protein dan lemak kacang merah berturut-turut adalah 25,78\% dan 1,92\% (Hayat et al. 2014). Nilai rata-rata kadar lemak tertinggi diperoleh dari proporsi pati sagu-tepung substitusi terbesar (70:30) yaitu $1,15 \% \mathrm{bk}$, sedangkan nilai terendah diperoleh dari mi pati sagu tanpa penambahan tepung substitusi yaitu $0,35 \% \mathrm{bk}$. Mi yang disubstitusi kacang-kacangan diketahui mengalami peningkatan kadar lemak dibandingkan dengan mi kontrol (100\% pati sagu), karena kacang-kacangan mengandung lemak berkisar (1-2\%) sehingga semakin tinggi rasio tepung kacang akan semakin tinggi pula kadar lemaknya.

Penggunaan jenis protein yang ditambahkan ke dalam mi juga akan menentukan kandungan protein pada produk yang disubstitusi. Penelitian Barcelon et al. (2015) menunjukkan bahwa pasta yang diperkaya kacang-kacangan lebih kaya protein dibandingkan mi pasta yang diperkaya bahan nabati lainnya seperti sayuran. Penambahan protein yang diisolasi dari kacangkacangan juga menentukan tinggi rendahnya kandungan protein. Hal ini tidak hanya terjadi pada pasta. Pada mi dengan substitusi tepung kacangkacangan juga mampu meningkatkan kandungan protein (Kumar \& Prabhasankar 2015).

\section{Sifat sensori mi pati sagu subsitusi tepung ka- cang}

Hasil analisis ragam (uji F) dan DMRT 5\% untuk sifat sensori mi dapat dilihat pada Tabel 4. Hasil uji statistik menunjukkan bahwa perlakuan jenis tepung substitusi (T) dan kombinasi perlakuan jenis tepung substitusi dan proporsi pati sagu-tepung subsitusi (TxP) tidak berpengaruh terhadap semua variabel sensori, sedangkan perlakuan proporsi pati sagu-tepung substitusi (P) berpengaruh hanya terhadap variabel warna.

Tabel 4. Hasil analisis ragam (Uji F) dan DMRT 5\% sifat sensori mi pati sagu

\begin{tabular}{ccccc}
\hline $\begin{array}{c}\text { Pengaruh Jenis Tepung } \\
\text { Substitusi (T) }\end{array}$ & Warna & Flavor & Tekstur & Kesukaan \\
\hline T1 & 2,846 & 2,779 & 2,471 & 2,396 \\
T2 & 2,815 & 2,755 & 2,441 & 2,419 \\
Pengaruh Proporsi (P) & & & & \\
P0 & 2,485 bc & 2,823 & 2,603 & 2,513 \\
P1 & $2,398 \mathrm{c}$ & 3,058 & 2,440 & 2,428 \\
P2 & $3,425 \mathrm{a}$ & 2,588 & 2,325 & 2,293 \\
P3 & $3,015 \mathrm{ab}$ & 2,600 & 2,458 & 2,398 \\
Pengaruh Interaksi (TxP) & & & & \\
T1P0 & $2,39 \pm 0,38$ & $2,83 \pm 0,04$ & $2,56 \pm 0,25$ & $2,44 \pm 0,21$ \\
T1P1 & $2,53 \pm 0,17$ & $2,94 \pm 0,04$ & $2,44 \pm 0,09$ & $2,44 \pm 0,04$ \\
T1P2 & $3,21 \pm 0,12$ & $2,74 \pm 0$ & $2,47 \pm 0,04$ & $2,35 \pm 0,17$ \\
T1P3 & $3,27 \pm 0,54$ & $2,62 \pm 0,42$ & $2,42 \pm 0,21$ & $2,36 \pm 0,33$ \\
T2P0 & $2,59 \pm 0,5$ & $2,82 \pm 0,16$ & $2,65 \pm 0,09$ & $2,59 \pm 0,25$ \\
T2P1 & $2,27 \pm 0,29$ & $3,18 \pm 0,71$ & $2,44 \pm 0,42$ & $2,42 \pm 0,67$ \\
T2P2 & $3,65 \pm 0,42$ & $2,44 \pm 1,0$ & $2,18 \pm 0,79$ & $2,24 \pm 1,08$ \\
T2P3 & $2,77 \pm 0,33$ & $2,59 \pm 0,21$ & $2,50 \pm 0,25$ & $2,44 \pm 0,29$ \\
\hline
\end{tabular}

*Angka yang diikuti huruf (a, b, c, d) yang berbeda pada kolom yang sama menunjukkan berbeda nyata (DMRT 5\%)

Keterangan: Warna 1)kuning, 2)kuning-cokelat, 3)cokelat, 4)sangat cokelat ; Flavor 1)tidak enak, 2)agak enak,

3)enak, 4)sangat enak; Tekstur 1)tidak kenyal, 2)agak kenyal, 3)kenyal, 4)sangat kenyal; Kesukaan 1)tidak suka,

2)agak suka, 3)suka, 4)sangat suka. 
Agustia dkk.

\section{Warna}

Gambar 3 menunjukkan nilai rata-rata warna mi pati sagu pada perlakuan proporsi pati sagu-tepung substitusi.

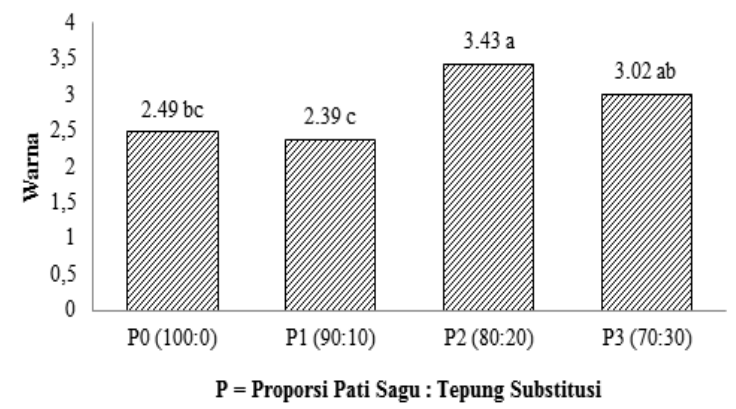

Warna: 1) kuning; 2)kuning-cokelat; 3)cokelat; 4) sangat cokelat

*Angka yang diikuti huruf yang sama tidak berbeda nyata pada DMRT $5 \%$.

Gambar 3. Nilai rata-rata warna mi pati sagu pada perlakuan proporsi pati sagu-tepung substitusi.

Warna mi pati sagu, lebih diakibatkan oleh reaksi pencokelatan non enzimatis Maillard. Berdasarkan Gambar 3, semakin tinggi proporsi pati sagu-tepung substitusi maka warna mi pati sagu cenderung semakin gelap. Hal ini karena pada proses pembuatan mi pati sagu menggunakan bahan substitusi tepung kacang merah dan tepung kacang hijau yang tinggi protein. Protein yang terkandung pada kacang merah menyebabkan terjadinya reaksi Maillard, yaitu reaksi pencokelatan non enzimatis antara gugus amino pada protein yang bereaksi dengan gula reduksi sehingga menghasilkan warna cokelat (Winarno 2004). Reaksi maillard pada proses pembuatan mi ini terjadi pada saat pemanasan adonan pasta pati sagu untuk pengentalan. Suhu pemanasan adalah salah satu faktor yang dapat meningkatkan intensitas reaksi maillard. Secara keseluruhan nilai rata-rata warna mi pati sagu berkisar antara 2,27-3,65 (kuning-cokelat sampai cokelat).

\section{Tekstur}

Penilaian tekstur mi pati sagu dalam penelitian ini adalah kekenyalannya. Nilai ratarata tekstur mi pati sagu terendah dan tertinggi berturut-turut yaitu 2,44 (agak kenyal) dan 3,18 (kenyal). Nilai rata-rata tekstur mi pati sagu tertinggi adalah pada T2P0 (tepung kacang merah, proporsi pati sagu : tepung kacang merah 100:0). Hal ini dikarenakan proses pembuatan mi pati sagu tersebut menggunakan $100 \%$ pati sagu tanpa penambahan tepung substitusi. Pati sagu tersusun dari $20 \%$ amilosa dan $80 \%$ amilopektin dengan sifat-sifat viskositas tinggi, bertekstur lunak, stabil terhadap retrogradasi, suhu gelatinisasi $60-70^{\circ} \mathrm{C}$ sehingga mendukung kekenyalan mi. Menurut penelitian Wu et al. (2015), penambahan mung bean starch (sejenis kacang hijau) dapat meningkatkan kadar amilosa dalam mi tepung beras yang akan meningkatan kualitas mi karena dapat membentuk gel yang kuat. Selain itu menurut Yuliani et al. (2015), mi kering sagu dengan substitusi kacang hijau 20\% memiliki tekstur yang paling optimum.

\section{Flavor}

Flavor merupakan salah satu variabel penentu dalam tingkat penerimaan panelis terhadap suatu produk. Flavor atau cita rasa merupakan sensasi yang dihasilkan oleh makanan ketika diletakkan dalam mulut terutama yang ditimbulkan oleh rasa dan bau (Soekarto 1985). Nilai rata-rata flavor mi pati sagu terendah dan tertinggi berturut-turut yaitu 2,18 (agak enak) dan 2,65 (agak enak). Nilai rata-rata flavor mi pati sagu tertinggi adalah pada T2P1 (tepung kacang merah, proporsi pati sagu:tepung kacang merah 90:10). Flavor kurang enak yang dihasilkan dari mi pati sagu berupa rasa langu yang diduga disebabkan oleh aktivitas enzim lipoksigenase pada tepung kacang merah dan kacang hijau sebagai tepung substitusi. Secara alami, enzim lipoksigenase terkandung pada kacang-kacangan dan akan aktif pada saat pengolahan kacang. Bau langu pada kacang merah dan kacang hijau dapat diminimalisir dengan proses perendaman dan perebusan saat pembuatan tepung kacang.

\section{Nilai kesukaan}

Nilai kesukaan dalam hal ini ialah kesukaan secara keseluruhan. Tingkat kesukaan panelis berhubungan erat dengan tingkat penerimaan konsumen terhadap suatu produk. Nilai rata-rata kesukaan mi pati sagu terendah dan tertinggi berturut-turut yaitu 2,24 (agak suka) dan 2,59 (agak suka). Nilai rata-rata kesukaan mi pati sagu tertinggi adalah pada T2P0 (tepung kacang merah, proporsi pati sagu:tepung kacang merah 100:0). Meskipun menggunakan tepung substitusi dari tepung kacang yang memiliki bau langu namun secara keseluruhan mi pati sagu substitusi tepung kacang disukai oleh panelis. Hal ini sesuai dengan penelitian Adegunwa et al. (2012), mi yang dibuat dari tepung terigu-ubikayu:tepung kedelai $(80: 10: 10) \%$ b/b disukai oleh panelis, dan Omeire et al. (2015) menyatakan mi dari tepung terigu-ubi kayu-tepung kedelai rendah lemak (80:10:10) \%b/b kaya akan protein dan memiliki nilai kesukaan tinggi. 


\section{Mi perlakuan terbaik}

Kombinasi terbaik yang diinginkan yaitu mi dengan kadar protein tinggi. Berdasarkan uji indeks efektifitas ditinjau dari sifat kimia dan sensori diperoleh perlakuan terbaik yaitu T2P3 (proporsi perlakuan pati sagu:tepung kacang merah 70\%:30\%) dengan kadar protein cukup tinggi yaitu $10,47 \% \mathrm{bk}$, kadar lemak 1,17\%bk, kadar air 68,99\%bb; kadar abu 1,19\%bk dan kadar karbohidrat by difference $18,18 \% \mathrm{bk}$, warna 2,77 (kuning-cokelat), tekstur 2,59 (agak kenyal), flavor 2,50 (agak enak) dan kesukaan 2,44 (agak suka). Mi hasil penelitian mengandung protein lebih tinggi daripada mi sagung (jagung:sagu = $1: 40)$ yang mengandung protein $7,80 \% \mathrm{bb}(\mathrm{Au}-$ liah 2012). Mi hasil penelitian sudah memenuhi standar mutu mi basah (SNI 01-2987-1992) yaitu mengandung protein minimal $8 \%$.

\section{KESIMPULAN}

Kombinasi perlakuan terbaik didapatkan dari proporsi perlakuan pati sagu:tepung kacang merah (70\%:30\%) dengan kadar protein cukup tinggi yaitu $10,47 \% \mathrm{bk}$. Mi hasil penelitian sudah memenuhi standar mutu mi basah (SNI 01-29871992).

Diperlukan penelitian lanjutan mengenai penambahan flavor misalnya lada hitam dan bawang putih untuk menutupi bau langu dari kacang-kacangan sehingga akan meningkatkan kesukaan.

\section{UCAPAN TERIMA KASIH}

Peneliti penyampaikan penghargaan yang tinggi dan terima kasih kepada Kementerian Pendidikan Tinggi dan Kebudayaan yang telah membiayai penelitian ini melalui program DIPA UNSOED Tahun 2014.

\section{DAFTAR PUSTAKA}

Adegunwa MO, Bakare HA, and Akinola OF. 2012. Enrichment of noodles with soy flour and carrot powder. NIFST 30(1): 7481.

Audu SS and Aremu MO. 2011. Effect of processing on chemical composition of red kidney bean (Phaseolus vulgaris L.) flour. PJN 10 (11): 1069-1075.

Auliah A. 2012. Formulasi Kombinasi Tepung Sagu dan Jagung pada Pembuatan Mi. J Chem 13(2): 33-38.

Barcelon EG. 2015. Vegetable-added pasta noodle: Physico-chemical composition and consumer acceptability. IJAIR 3(6), ISSN (Online) 2319-1473.

Chairil MMF dan Kustiyah L. 2014. Formulasi flakes berbasis pati garut dengan fortifikasi zat besi $(\mathrm{Fe})$ untuk perbaikan status besi remaja putri. J Gizi Pangan 9(2):89-96.

Chillo S, Monro JA, Mishra S, Henry CJ. 2010. Effect of incorporating legume flour into semolina spaghetti on its cooking quality and glycaemic impactmeasured in vitro, Int J Food Sci Nutr 61(2): 149-160.

Dahiya PK, Khetarpaul N, Linnemann AR, Grewal RB, Van Boekel MAJS, Nout MJR. 2015. Mung bean: Technological and nutritional potential. Crit Rev Food Sci Nutr 55:670-688.

Dahiya PK, MJR Nout and Martinus A. van Boekel. 2014. Nutritional characteristics of mung bean foods. BFJ 116(6).

Gardjito M, Djuwardi A, dan Hermayani A. 2013. Pangan Nusantara "Karakteristik dan Prospek untuk Percepatan Diversifikasi Pangan. Jakarta: Kencana Prenada Media Group.

Hayat I, A Ahmad, A Ahmed, S Khalil and M Gulfraz. 2014. Exploring the potential of red kidney beans (Phaseolus Vulgaris L.) to develop protein based product for food applications. JAPS 24(3):860-868.

Hormdok R and Noomhorn A. 2007. Hydrothermal treatment of rice starch for improvement of rice noodle quality. LWT-Food Sci Technol 40:1723-1731.

Hu XZ, Wei YM, Wang C and Kovac MIP. 2007. Quantitative assesment of protein fraction of chinese wheat flours and their contribution on white salted noodle quality. Food Res Int 40:1-6.

Kumar SB and Prabhasankar PA. 2015. Study on starch profile of rajma bean (Phaseolus vulgaris) incorporated noodle dough and its functional characteristics. Food Chem 180:124-132.

Muhammad K, Kusnandar F, Hashim DM and Rahman, RA. 1999. Application of native and phosphorilated tapioca starches in potato starch noodle. IJFST $34: 275-280$.

Omeire GC, Kabuo NO, Nwosu JN, Peter-Ikechukwu A and Nwosu MO. 2015. Enrichment of wheat/cassava noodles with partially deffated protein-rich flour. IOSRJESTFT 9(5) I.

Omeire GC, Nwosu JN, Kabuo NO and Nwosu MO. 2015. Cooking properties and sensory evaluation of enriched cassava/wheat noodles. IJIRST 3(2). 
Agustia dkk.

Perdana F dan Hardinsyah. 2013. Analisis jenis, jumlah dan mutu gizi konsumsi sarapan Anak Indonesia. J Gizi Pangan 8(1):39-46.

[SNI] Standar Nasional Indonesia.1992. SNI 01-2891-1992. Mi Basah. Jakarta: Badan Standardisasi Nasional.

Soekarto ST. 1985. Penilaian Organoleptik untuk Industri pangan. Surabaya: Bina Ilmu.

Sudarmadji S, Bambang H, Suhardi. 1984. Prosedur Analisa untuk Bahan Makanan dan Pertanian. Yogyakarta: Liberty.
Tam LM, Corke H, Tan WT, Li J dan Collado LS. 2004. Production of bihon type-noodle from maize starch differing in amylose content. Cereal Chem 81(4): 475-480.

Winarno FG. 2004. Kimia Pangan dan Gizi. Jakarta: PT Gramedia Pustaka Utama.

Wu F, Meng Y, Yang N, Tao H, Xu X. 2015. Effects of mung bean starch on quality of rice noodles made by dry flour extrusion. Food Sci Technol 63:1199-1205.

Yuliani H, Yuliana ND dan Budijanto, S. 2015. Formulasi mi kering sagu dengan substitusi tepung kacang hijau. Agritech 35(4). 